\title{
У Sairaalasielunhoitotyön asiantuntijuus sairaalasielunhoitajan näkökulmasta
}

Tutkimuksessa kuvataan sairaalasielunhoitajan asiantuntijuutta ja siihen yhteydessä olevia tekijöitä. Tutkimusaineisto kerättiin sairaalasielunhoitajilta $(n=83)$ sähköisellä kyselylomakkeella, joka sisälsi Likert-asteikollisia sielunhoitotyön asiantuntijuuteen liittyviä kysymyksiä ja niihin liittyviä taustatietoja.

Keskustelussa potilaan kanssa sairaalasielunhoitajat käsittelivät pääasiassa sairastumista, elämänkrïsejä ja surua. He työskentelivät enimmäkseen kuunnellen, myötäeläen, ottamalla vastaan potilaan tunteita ja keskustellen. Keskeiset tavoitteet sielunhoitotyössä olivat toivon ylläpitäminen ja ihmisarvon vahvistuminen, sekä potilaan turvallisuuden tunteen lisääntyminen. Työssään tärkeimmiksi asioiksi potilaalle sairaalasielunhoitajat arvioivat mahdollisuuden keskustella, mahdollisuuden keskustella peloista sekä tuen surussa ja hoitajille mahdollisuuden krïsitukeen, hengellisen asiantuntija-avun ja sielunhoidollisen tuen potilaalle. Keskeiset työtehtävät olivat keskusteluapu, tuki kuoleman kohtaamisessa ja surevien tukeminen. Sairaalasielunhoitajat arvioivat olevansa luotettavia, rauhallisia ja asiakaslähtöisiä. Heille tärkeimmät arvot työssä olivat sielunhoidettavan kunnioittaminen, itsemääräämisoikeuden ja vakaumuksen tukeminen. Terveydenhuollon yksikkö tai lisäkoulutus ei vaikuttanut merkittävästi sairaalasielunhoitajien työmenetelmiin, tavoitteisiin tai käsitykseen työtehtävistä. Potilaan tukeminen tunteiden tunnistamiseen ja käsittelyyn sekä eettisten kysymysten käsittely lisääntyivät työkokemuksen kasvaessa.

ASIASANAT: Sielunhoito, sairaalasielunhoito, sairaala, spiritualiteetti VIRPI SIPOLA, IKALI KARVINEN, HEINI HUHTALA, PÄIVI ASTEDT-KURKI, ANNA LIISA AHO

\section{YDINASIAT}

- Sielunhoidollinen tuki ja myötätuntoinen kohtaaminen vaikuttavat potilaan ja läheisten hyvinvointiin.

- Sairaalasielunhoitajan pidempi työssäoloaika on yhteydessä laaja-alaisempien teemojen käsittelyyn potilaan kanssa ja tavoitteeseen tukea potilasta tunnistamaan ja käsittelemään tunteita.

- Tieto tukee moniammatillisen yhteistyön ja sairaalasielunhoitajien työn ja erityiskoulutuksen kehittämistä.

- Työn vaikuttavuutta potilaan ja hoitohenkilökunnan hyvinvointiin tulisi tutkia lisää.

\section{JOHDANTO}

Sairaalasielunhoito tarkoittaa ammatillista toimintaa, jota toteuttaa evankelis-luterilaisen kirkon sairaalapappi eli sairaalasielunhoitaja. Sairaalasielunhoitaja on koulutukseltaan teologian maisteri ja hänellä on sairaalasielunhoitajan erityiskoulutus (60 op). Työ ulottuu kaikille terveydenhuollon tasoille erityissairaanhoidosta avoterveydenhuoltoon. Sairaalasielunhoito tarkoittaa potilaan vakaumuksen mukaista eksistentiaalista tukea. Työskentelyn tehtävänä on ihmisen auttaminen oman elämänsä syvälliseen ymmärtämiseen. Se on tukemista elämän muutostilanteissa, vakavassa sairas- 
tumisessa ja kuolemassa (1). Sairaalasielunhoitotyössä ihminen kohdataan kokonaisuutena. Sairaalasielunhoitaja tukee myös läheisiä ja henkilökuntaa hoitotyön arjessa ja vaativissa kriisitilanteissa, antaa työnohjausta ja huolehtii kirkollisista toimituksista. Hän vastaa erilaisiin uskontokuntiin kuuluvien henkisestä tuesta ja kutsuu pyydettäessä paikalle potilaan oman uskontokunnan edustajan. Sairaalasielunhoitaja toimii tukena henkisissä ja elämänkatsomuksellisissa kysymyksissä kaikille, vakaumuksesta riippumatta (1). Terveydenhuollon muutokset, sairaansijojen väheneminen, avohoidon ja hoivayksiköiden lisääntyminen, lyhentyneet hoitoajat ja hoitoisuusasteen nousu, kuormittavat hoitohenkilökuntaa ja ovat lisänneet työnohjauksellisen tuen tarvetta. Sairaalasielunhoitajan työkentän kulttuurinen ja uskonnollinen moninaistuminen edellyttävät uudenlaista ammatillista osaamista ja uskonnollisuuden ymmärtämistä avarammin henkisinä ja spirituaalisina merkityksinä (2). Hengellisessä ja henkisessä tuessa tulisi nykyistä paremmin huomioi$\mathrm{da}$ historiallinen ja kulttuurinen viitekehys ja tuen tulisi toteutua yksilöä arvostavana hoidon kaikilla tasoilla (3). Hengellisyydellä käsitetään yksilön tapaa etsiä ja ilmaista merkitystä, tarkoitusta ja tapaa, jonka avulla hän kokee yhteyttä hetkeen, itseen, toisiin, luontoon ja pyhään (4). Se on osa laadukasta terveydenhuoltoa ja toteutuu myötätunnon osoittamisena, asenteina ja käytännön toimina $(3,5)$. Hengellisten tarpeiden huomioiminen kuuluu lääkärin ja hoitajan tehtäviin. Tarpeisiin vastaaminen delegoidaan kuitenkin usein sairaalasielunhoitajalle (6). Henkinen ja hengellinen tuki kohdistuu eksistentiaalisiin kysymyksiin. Se on läsnäoloa ja kuuntelua, vastavuoroista keskustelua ja lohduttamista (7). Potilaan oikeus henkiseen ja hengelliseen tukeen perustuu lainsäädäntöön ja hoidon etiikkaan (8).

Moninaisiin henkisiin ja hengellisiin tarpeisiin vastaaminen edellyttää sairaalasielunhoitajalta laajaa asiantuntijuutta (9). Asiantuntijuus merkitsee itsetuntemukseen, arvomaailmaan, elämänhistoriaan, ihmiskäsitykseen, sosiokulttuuriin ja alan teoreettiseen tietämiseen liittyvää tietoa ja osaamista. Se tarkoittaa ongelmaratkaisutaitoja, käytännön osaamiseen ja toiminnan säätelyyn liittyvän tiedon ja itsearviointiin liittyvän osaamisen yhdistymistä henkilön toiminnassa $(10,11,12)$. Tässä tutkimuksessa tarkastellaan työmenetelmiä ja sairaalasielunhoitajan työlleen asettamia tavoitteita. Nämä kertovat työtä koskevaan tietämiseen liittyvästä osaamisesta ja tiedosta, sekä niiden yhdistymisestä henkilön toiminnassa. Lisäksi tutkitaan työntekijän arviota työn merkityksestä potilaille ja hoitohenkilökunnalle, työtehtäviä ja ammatti-identiteettiä. Sielunhoitajan identiteetti tarkoittaa käsitystä itsestä sielunhoitajana ja ammattikuntansa edustajana. Siihen vaikuttavat mm. koulutus, työn reflektointi, työnohjaus, ammatillinen kasvu, työasenne, roolit, arvot, etiikka, tavoitteet ja usko (13). Sairaalasielunhoitajien omaa persoonaa, sekä asennetta potilasta kohtaan koskevat näkemykset työtehtävässä toimiessaan, kertovat itsetuntemuksesta ja arvoista.

Toimintatilastojen mukaan sairaalasielunhoitajat (n=129) kävivät työssään 64291 henkilökohtaista keskustelua potilaan, läheisen tai terveydenhuollon ammattihenkilön kanssa. He ohjasivat kriisi- suru- ja sielunhoitoryhmiä 1354 kertaa, antoivat 1702 tuntia yksilö- tai ryhmätyönohjausta ja järjestivät erilaisia tilaisuuksia 2640 kertaa (14). Asiakaspalautetta on kerätty mm. Seinäjoen ja Mikkelin keskussairaaloissa. Sairaalasielunhoitotyön laadun ja koulutuksen kehittäminen edellyttää laajemmin tietoa työhön liittyvästä asiantuntijuudesta. Tutkimuksissa on havaittu sairaalasielunhoitajan vierailun helpottavan potilaan sairaalassaoloa (15). On myös todettu spiritualiteetin merkitys potilaan hyvinvoinnissa (16) ja myötätunnon merkitys potilaan henkisessä tuessa (17). Potilaalle merkitykselliseksi on havaittu henkinen tuki, luottamuksellinen keskustelu ja ratkaisujen löytäminen vaikeissa asioissa. Hoitajille puolestaan tuki hoitotyössä, henkinen tuki ja kriisituki potilaalle ja perheelle $(9,18,19,20)$.

Hyvän sielunhoitokeskustelun on havaittu rakentuvan luottamuksesta, yksilöllisestä kohtaamisesta, ammattitaidosta ja kokemuksesta. Hyvän sielunhoitajan ominaisuuksiksi on todettu taito tukea kokonaisvaltaisesti, kuunteleminen, empaattisuus, elämänkokemus ja kiinnostuneisuus ihmisistä $(9,21)$. Tärkeimmäksi työvälineeksi on havaittu persoona, läsnäolo, potilaan ja tämän elämäntilanteen vastaanottaminen ja tapa vastata olemassaolon kysymyksiin (22). Lisäksi on havaittu sielunhoitajan tehtävään liittyvä persoonallinen kasvu $(23,24)$. Työn tavoitteeksi on havaittu potilaan tukeminen jokapäiväisessä selviytymisessä ja vaikeissa tilanteissa, hoitoluot- 
tamuksen lisääntyminen, sairaalassaolon helpottuminen, hengellisyyden ja emotionaalisen hyvinvoinnin tukeminen $(9,18,20)$.

Sairaalasielunhoitajan työn kehittämistä, vaikutuksia potilaaseen ja hoitotuloksiin koskevissa tutkimuksissa on havaittu, että potilasta auttaneen työskentelyn merkittävin osa on sielunhoitajan ja potilaan vuorovaikutussuhde $(20,25,26)$. Sairaalasielunhoitajat käyttävät persoonaansa ja vuorovaikutussuhdetta potilaaseen arvioidessaan potilaan henkisiä tarpeita, valitessaan tukikeinon ja arvioidessaan tuen vaikutuksia. He hyödyntävät kuuntelemista, havainnointia ja omia luonnollisia reaktioitaan reagoida potilaan ensisijaiseen tarpeeseen (5).

On havaittu, että puolet sairaalasielunhoitajan vierailusta potilaan luona on uskonnollista, kolmasosa henkistä ja viidesosa emotionaalista tukemista (27). Lisäksi on havaittu, että aktiivinen, empaattinen kuunteleminen (21), sairaudesta puhuminen, tuki ihmissuhdeongelmissa ja elämänvaikeuksissa ovat keskeisimmät elementit ja uskonnollisen toiminnan osuus pieni. Keskustelu sairaalasielunhoitajan kanssa koetaan uskonnollissävytteiseksi, vaikkakaan kristillinen elämänkatsomus ei ole merkittävä asia kaikille sielunhoitoa toivoville $(9,28)$.

Suomessa sairaalasielunhoitajien työnantaja on evankelis-luterilainen kirkko, vaikka he työskentelevät terveydenhuollossa. Sen on havaittu vaikuttavan sairaalapapin ammatti-identiteetin muodostumiseen. Ammatti-identiteetti muodostui tehtäväkeskeisestä sitoutumisesta ja ryhmään kuulumisesta (29). Sairaalasielunhoitajilla on tunnistettu kolme työorientaatioita: hengellisyyttä painottava, potilaan yksilöllistä tilannetta korostava ja potilaan tarpeista käsin työskentelevä työntekijä (29). Sairaalapappien käsityksiä asiantuntijuudestaan ei ole aikaisemmin tutkittu.

\section{TUTKIMUKSEN TARKOITUS JA TUTKIMUSKYSYMYKSET}

Tutkimuksen tarkoituksena on kuvata sairaalasielunhoitajan asiantuntijuutta sairaalasielunhoitajan näkökulmasta tuottaen tietoa sairaalasielunhoitotyöhön, sekä työn ja koulutuksen kehittämiseen.

Tutkimuskysymykset:

1. Millaisena sairaalasielunhoitajat kokevat oman asiantuntijuutensa?

2. Mitkä asiat ovat yhteydessä sairaalasielunhoitajan asiantuntijuuteen?

\section{TUTKIMUKSEEN OSALLISTUJAT JA AINEISTON KERUU}

Tieto kerättiin kyselylomakkeella kaikilta sosiaalija terveydenhuollossa päätoimisesti työskenteleviltä sairaalasielunhoitajilta $(n=127)$ ja muilta seurakunnan työntekijöiltä $(\mathrm{n}=4)$. Kyselylomake lähetettiin sähköpostitse Kirkkohallituksen Diakonian ja Sielunhoidon yksikön hallussa olevia yhteystietoja hyödyntäen. Määräaikana 83 sairaalasielunhoitajaa $(63.4 \%)$ vastasi kyselylomakkeeseen. Asiantuntijuuden mittaamista varten kehitettiin mittari aikaisempaa tutkimusta ja asiantuntijatietoa hyödyntäen. Tiedonhaku tehtiin tietokantoihin Medline, Cinahl, PsycINFO, Linda, Medic ja Helda. Tutkimuksessa käytettiin 22 artikkelia (lähdeluettelo). Mittari sisälsi kymmenen vastaajien taustatietoja mittaavaa kysymystä (taulukko

1.) Lisäksi kysyttiin sairaalasielunhoitajan asiantuntijuuteen liittyen, millaisia teemoja hän käsittelee sielunhoitokeskustelussa potilaan kanssa, millaisia työskentelytapoja ja tukikeinoja hän käyttää sielunhoitokeskustelussa ja millaisia tavoitteita hän asettaa työlleen. Mittarissa kysyttiin myös, millaiseksi sairaalasielunhoitaja arvio työnsä merkityksen potilaalle ja hoitajalle, mitä ovat sairaalasielunhoitajan työtehtävät ja miten hän kuvaa ammatillista identiteettiään. Kysymykset esitettiin viisiasteisena Likert -asteikolla mitattuna (1=täysin eri mieltä, 2=jokseenkin eri mieltä, 3=ei samaa eikä eri mieltä, 4=jokseenkin samaa mieltä, 5=täysin samaa mieltä). Mittarin arvioinnissa hyödynnettiin sairaalasielunhoitotyötä tehneitä asiantuntijoita $(\mathrm{n}=2)$. Esitestaus toteutettiin sairaalasielunhoitajille $(\mathrm{n}=8)$ erityiskoulutuksen yhteydessä.

\section{AINEISTON ANALYYSI}

Taustamuuttujat kuvattiin prosentti- ja frekvenssiosuuksina. Aineiston Likert-asteikolliset sairaalasielunhoitotyön asiantuntijuutta kuvaavat kysymykset analysoitiin SPSS -ohjelmiston avulla. Yhteyksiä taustatekijämuuttujien ja Likert-asteikollisista kysymyksistä muodostuneiden muuttujien välillä tarkasteltiin ristiintaulukoinnin, khiin neliötestin ja Fisherin testin avulla. Sairaalasielunhoitajan työkokemusta koskevassa vastauksessa vastaajien puuttuvat tiedot $(n=2)$, korvattiin vastaajien työkokemusta koskevan vastauksen keskiarvolla (30). Avokysymykset tyypiteltiin ja luokiteltiin. Alkuperäiset ilmaukset tiivistettiin ja niistä muodostettiin alakategorioita ja yläkategorioita (31). 


\section{TUTKIMUKSEN TULOKSET}

\section{SAIRAALASIELUNHOITAJIEN TAUSTATIEDOT}

Vastaajista enemmistö oli naisia. Puolet vastaajista oli työskennellyt sairaalasielunhoitajana 6-19 vuotta (Md 11 vuotta, Ka 12 vuotta). Nykyisessä työyksikössä vastaajat olivat työskennelleet keskimäärin 9 vuotta (Md 7 vuotta).

Taulukko 1. Vastaajien taustatiedot ja työhön liittyvät taustatekijät ( $\mathrm{n}=83)$

\begin{tabular}{|c|c|c|}
\hline Taustatekijät & $\mathrm{n}$ & $\%$ \\
\hline \multicolumn{3}{|l|}{ Ikä vuosina } \\
\hline $35-44$ & 12 & 14 \\
\hline $45-54$ & 31 & 37 \\
\hline $55-65$ & 41 & 49 \\
\hline \multicolumn{3}{|l|}{ Siviilisääty } \\
\hline parisuhteessa tai naimisissa & 70 & 84 \\
\hline yksineläjä & 13 & 16 \\
\hline \multicolumn{3}{|l|}{ Peruskoulutus } \\
\hline keski- tai peruskoulu & 3 & 5 \\
\hline lukio & 80 & 95 \\
\hline \multicolumn{3}{|l|}{ Ammatillinen koulutus } \\
\hline teologian maisterin tutkinto & 79 & 95 \\
\hline sairaalasielunhoitajan erityiskoulutus & 54 & 65 \\
\hline työnohjaajakoulutus & 45 & 54 \\
\hline työyhteisökonsultin koulutus & 9 & 11 \\
\hline psykoterapeutin koulutus & 7 & 8 \\
\hline jokin muu koulutus & 18 & 22 \\
\hline toinen korkeakoulututkinto & 7 & 8 \\
\hline ammattikoulu tai kurssi & 3 & 4 \\
\hline \multicolumn{3}{|l|}{ Työalue } \\
\hline Etelä-suomi & 44 & 53 \\
\hline Länsi-suomi & 29 & 35 \\
\hline Itä-suomi & 10 & 12 \\
\hline \multicolumn{3}{|l|}{ Työvuodet sairaalasielunhoitajana } \\
\hline$<5$ & 14 & 17 \\
\hline $5-14$ & 42 & 51 \\
\hline $15-24$ & 19 & 25 \\
\hline $25-34$ & 8 & 10 \\
\hline \multicolumn{3}{|l|}{ Aikaisempi työkokemus papin työstä muualla kuin sairaalassa } \\
\hline seurakunta & 70 & 84 \\
\hline oppilaitos & 6 & 7 \\
\hline järjestö & 7 & 8 \\
\hline ulkomailla kirkon työssä & 6 & 7 \\
\hline \multicolumn{3}{|l|}{ Tämänhetkinen työpaikka terveydenhuollossa } \\
\hline yleis-, kaupungin- tai terveyskeskussairaala & 83 & 100 \\
\hline psykiatrinen sairaala & 26 & 31 \\
\hline vanhusten palvelukeskus tai geriatrinen yksikkö & 37 & 44 \\
\hline yliopistollinen sairaala & 22 & 27 \\
\hline kotisairaala tai kotisairaanhoito & 5 & 20 \\
\hline lasten tai nuorten sairaala & 6 & 7 \\
\hline yksityinen hoivakoti & 7 & 8 \\
\hline jokin muu & 12 & 14 \\
\hline \multicolumn{3}{|l|}{ Työssäolovuodet nykyisessä yksikössä } \\
\hline $1-5$ & 36 & 43 \\
\hline $6-15$ & 31 & 37 \\
\hline $16-25$ & 14 & 17 \\
\hline $26-34$ & 2 & 2 \\
\hline \multicolumn{3}{|l|}{ Osastot, joilla työskentelee } \\
\hline teho-osasto & 30 & 36 \\
\hline palliatiivinen tai saattohoito-osasto & 56 & 68 \\
\hline psykiatrinen osasto, psykogeriatrinen osasto, poliklinikka & 76 & 92 \\
\hline syöpätautien osasto & 23 & 28 \\
\hline sisätautien tai kirurgian osasto & 80 & 96 \\
\hline lasten- tai naistentautien osasto, synnytysosasto & 59 & 71 \\
\hline palveluasumisen yksikkö, geriatrinen osasto & 45 & 54 \\
\hline potilaan koti & 22 & 27 \\
\hline kuntouttava osasto, terveyskeskuksen vuodeosasto & 67 & 81 \\
\hline
\end{tabular}


Sairaalasielunhoitajat työskentelivät lisäksi sairaalakoulussa, vanhustenhoidossa, päihdehoidossa, sydänkeskuksessa, iho- ja infektio-osastoilla ja traumaosastoilla. Päivystystehtävissä he työskentelivät kaikissa sairaaloissa, niiden eri osastoilla. Aikaisempaa työkokemusta vastaajilla oli toisen erityistyömuodon $(5 \%, n=4)$, uskonnollisen yhteisön $(1 \%, \mathrm{n}=1)$ tai puolustusvoimien papin työstä $(4 \%, n=3)$. Vastaajat pitivät hengellisyyttä merkittävänä $(26 \%, n=30)$ tai erittäin merkittävänä $63 \%,(n=52)$ omassa elämässään. Sairaalasielunhoitajan työhön hakeutumisen syitä olivat halu tehdä sielunhoitotyötä $(55 \%, \mathrm{n}=46)$, halu auttaa $(43 \%, n=36)$, kutsumus $(39 \%, n=32)$, halu kertoa armosta sairaille ja kärsiville $(23 \%$, $\mathrm{n}=19)$ sekä mahdollisuus tehdä itsenäistä työtä $(20 \%, n=17)$.

\section{SAIRAALASIELUNHOITAJAN ASIANTUNTIJUUTTA KUVAAVAT ASIAT}

Sielunhoitokeskustelussa potilaan kanssa käsitellyt teemat Keskustellessaan potilaan kanssa, sairaalasielunhoitajat käsittelivät pääasiassa sairastumista $(87 \%, n=72)$, elämänkriisejä $(78 \%, n=65)$, surua $(76 \%, \mathrm{n}=63)$, kuoleman kohtaamista $(72 \%, \mathrm{n}=60)$, menetyksiä $(70 \%, n=58)$ ja pelkoja $(69 \%, n=57)$.

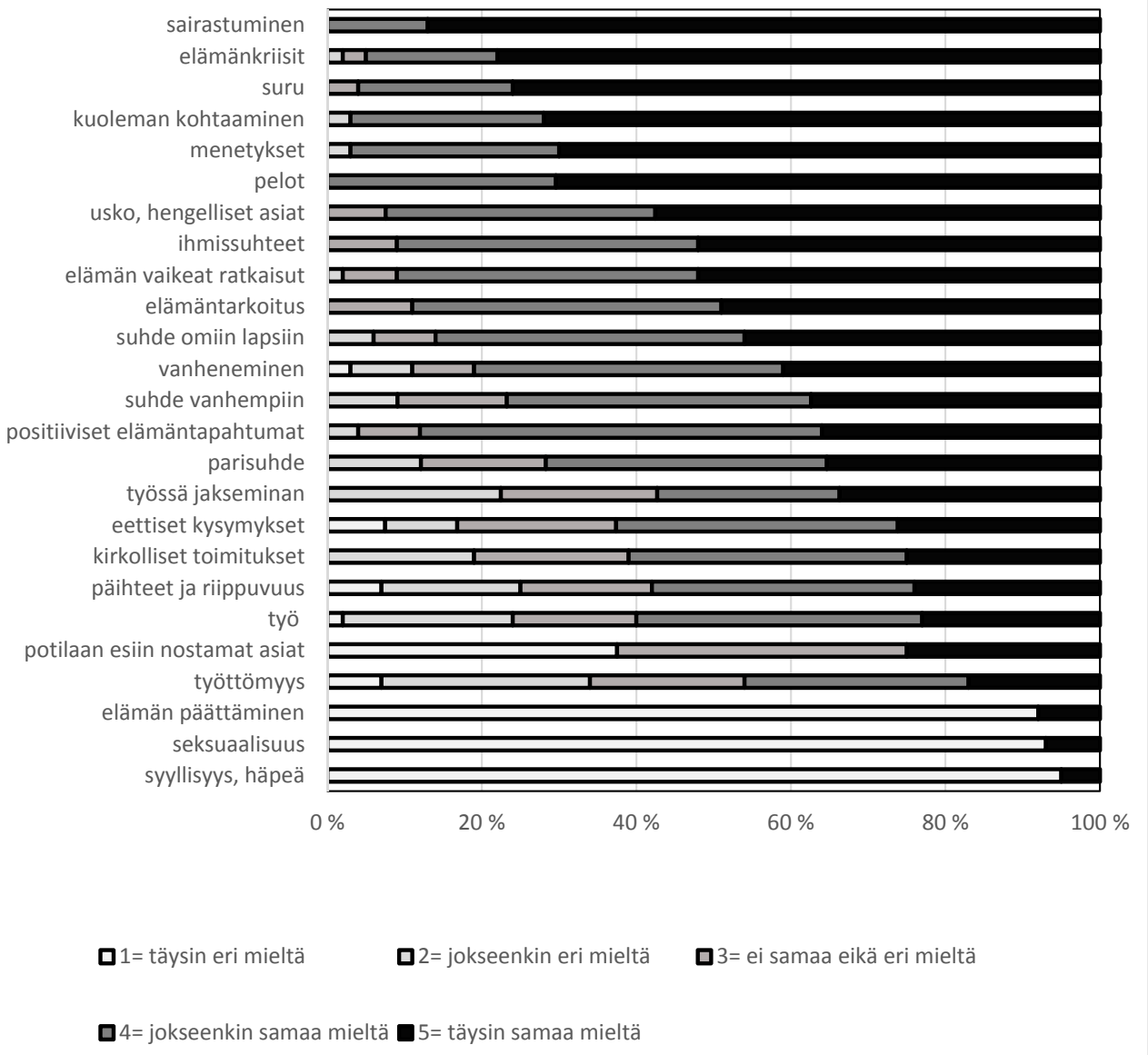

Kuvio 1. Teemat, joita sairaalasielunhoitajat käsittelivät potilaan kanssa ( $\mathrm{n}=83$ ). 
Sairaalasielunhoitajan työskentelytavat, potilaan tukemisen keinot ja sielunhoitotyön tavoitteet

Keskeisimmät työskentelytavat olivat potilaan kuunteleminen $(94 \%, n=78)$, myötäeläminen ja tunteiden vastaanottaminen $(90 \%, \mathrm{n}=74)$ ja keskustelutuki (84\%, $n=70)$.

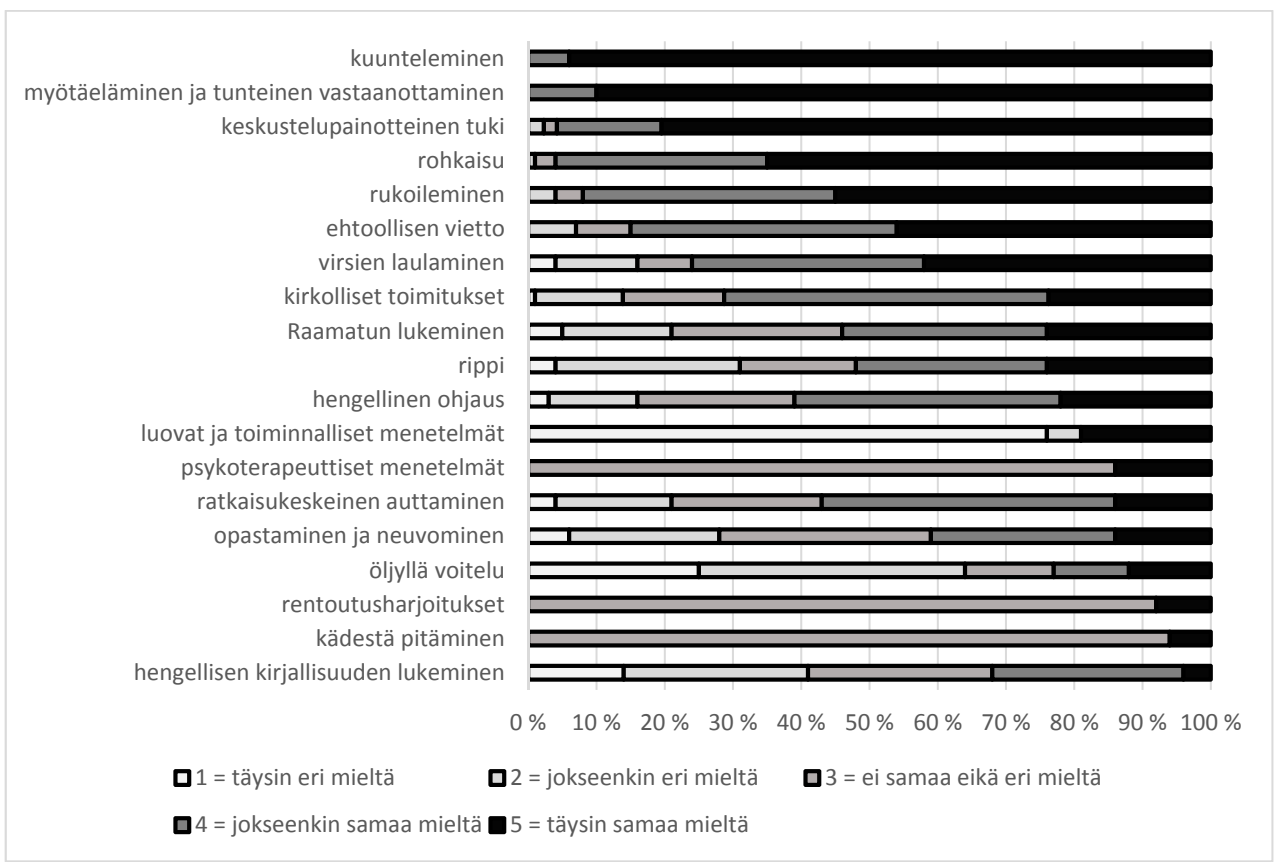

Kuvio 2. Sairaalasielunhoitajien työskentelytavat ja potilaan tukemisen keinot $(n=83)$.

Sielunhoitotyössä potilaan kanssa tärkeimmät ta- vahvistuminen $(84 \%)$, sekä potilaan turvoitteet olivat toivon ylläpitäminen ja ihmisarvon vallisuuden tunteen lisääntyminen $(80 \%)$.

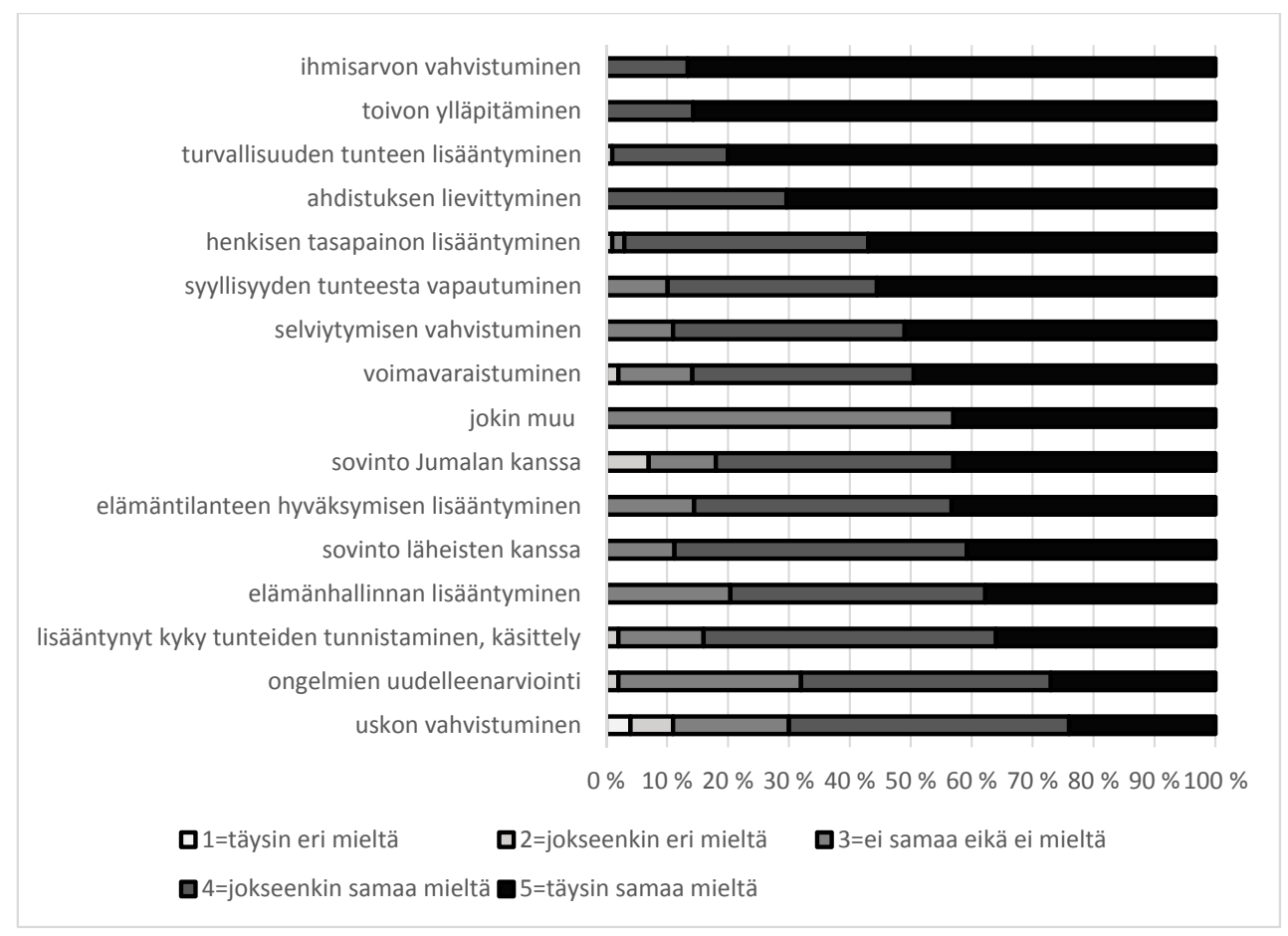

Kuvio 3. Tavoitteet sielunhoitotyössä potilaan kanssa $(\mathrm{n}=83)$. 


\section{Arvio työn merkityksestä potilaalle}

Potilaalle tärkeiksi asioiksi sairaalasielunhoitajat arvioivat keskustelumahdollisuuden $(95 \%, \mathrm{n}=79)$, mahdollisuuden käsitellä pelkoja $(89 \%, \mathrm{n}=74)$ ja tuen saamisen surussa $(89 \%, n=74)$. Vähiten tärkeiksi asioiksi potilaalle he arvioivat mahdollisuuden osallistua yhteiseen hartauteen (49\%, $\mathrm{n}=41$ ), mahdollisuuden harjoittaa uskontoa ja kuulla pyhän kirjan sanaa $(54 \%, n=45)$ sekä kirkollisen toimituksen järjestämisen $(58 \%, \mathrm{n}=48)$.

Mittarissa esitettyjen vaihtoehtojen lisäksi vastaajat $(47 \%, n=39)$ arvioivat potilaalle tärkeiksi asioiksi mahdollisuuden kokonaisvaltaiseen, hyväksyvään kohtaamiseen $(49 \%, n=19)$, luottamuksellisen keskustelun $(41 \%, \mathrm{n}=16)$, asiakaslähtöisyyden $(26 \%, n=10)$, osallisuuden kokemuksen $(23 \%, n=9)$, kiireettömän läsnäolon ja välittämisen $(13 \%, \mathrm{n}=5)$ ja kokemuksen Jumalan läsnäolosta $(5 \%, \mathrm{n}=2)$.

\section{Arvio työn merkityksestä hoitajille}

Hoitajille tärkeiksi asioiksi sairaalasielunhoitajat arvioivat mahdollisuuden kriisitukeen $(87 \%$, $\mathrm{n}=72)$ ja hengelliseen asiantuntija-apuun $(87 \%$, $\mathrm{n}=72$ ), sielunhoidollisen tuen saamisen potilaalle $(86 \%, n=71)$ ja läheiselle $(75 \%, n=62)$ sekä keskustelumahdollisuuden eettisistä kysymyksistä $(64 \%, n=53)$. Vähiten tärkeiksi asioiksi he arvioivat mahdollisuuden keskustella hengellisistä asioista $(54 \%, \mathrm{n}=45)$, saada sielunhoitoa $(46 \%$, $\mathrm{n}=38)$ ja kirkolliset toimitukset $(34 \%, \mathrm{n}=28)$.

\section{Sairaalasielunhoitajan työtehtävät}

Työtehtävikseen sairaalasielunhoitajat nimesivät keskusteluavun $(96 \%, \mathrm{n}=80)$, tuen kuoleman kohtaamisessa $(94 \%, n=78)$, surevien tukemisen (93\%, $n=77)$, kriisituen $(88 \%, n=73)$, henkisen hyvinvoinnin tukemisen ja masentuneen tukemisen $(81 \%, n=67)$. Myös henkinen hoito $(78 \%$, $\mathrm{n}=65)$, uskonnollinen asiantuntijuus $(76 \%, \mathrm{n}=63)$, rukoileminen $(75 \%, \mathrm{n}=62)$, uskonnollinen toiminta $(69 \%, n=57)$, koulutustehtävät $(58 \%, n=48)$, terapeuttinen tuki $(43 \%, \mathrm{n}=36)$, työnohjaus $(42 \%, n=35)$ ja debriefing- toiminta $(41 \%, n=34)$ nimettiin työtehtäviksi.

Avokysymykseen vastanneiden ( $\mathrm{n}=31) \mathrm{mu}-$ kaan työhön kuului verkostoyhteistyö (74\%, $\mathrm{n}=23)$, ohjaus- ja koulutustehtävät $(42 \%, \mathrm{n}=13)$, potilaiden, omaisten ja hoitajien tukeminen (35\%, $\mathrm{n}=11)$, tilaisuuksien järjestäminen $(32 \%$, $\mathrm{n}=10)$, hengellinen tuki $(26 \%, \mathrm{n}=8)$ ja moniam- matillinen työryhmätyöskentely $(26 \%, \mathrm{n}=8)$. Myös työyhteisötyö ja lähiesimiehen tehtävät $(13 \%, n=4)$, tiedottaminen $(10 \%, n=3)$, terveydenhuollon asioiden seuraaminen $(10 \%, n=3)$ ja työn kehittäminen $(10 \%, n=3)$ kuuluivat työhön.

\section{Sairaalasielunhoitajan arvio ammatti-identiteetistään}

Sairaalasielunhoitajat arvioivat olevansa luotettavia $(86 \%, \mathrm{n}=71)$, rauhallisia $(75 \%, \mathrm{n}=62)$, asiakaslähtöisiä (72\%, $\mathrm{n}=60)$, empaattisia $(70 \%$, $\mathrm{n}=58)$, elämänkokemusta omaavia $(69 \%, \mathrm{n}=57)$, ymmärtäväisiä ja hyviä kuuntelijoita (63\%, $\mathrm{n}=52)$. He pitivät itseään avoimina $(53 \%, \mathrm{n}=44)$, sallivina (52\%, $\mathrm{n}=43)$, ammatillisina $(49 \%$, $\mathrm{n}=41)$, hyvinä keskustelijoina $(46 \%, \mathrm{n}=38)$ ja kiireettöminä $(40 \%, n=33)$. Osa koki itsensä kantaaottavaksi $(31 \%, \mathrm{n}=26)$, asiantuntevaksi $(30 \%$, $\mathrm{n}=25)$, uskonnolliseksi $(25 \%, \mathrm{n}=21)$ ja älykkääksi $(17 \%, n=14)$.

Työtä ohjaavia arvoja olivat sielunhoidettavan kunnioittaminen $(98 \%, \mathrm{n}=81)$, itsemääräämisoikeuden ja vakaumuksen $(86 \%, n=71)$, sekä hyvinvoinnin $(75 \%, \mathrm{n}=62)$ tukeminen. Myös yksityisyyden ja potilasturvallisuuden huomioiminen $(72 \%, n=60)$, oikeudenmukaisuus $(66 \%$, $\mathrm{n}=55)$, ammattitaito $(62 \%, \mathrm{n}=51)$, tavoitettavuus $(42 \%, n=35)$ ja toiminnan oikea-aikaisuus $(20 \%, n=17)$, olivat tärkeitä arvoja.

\section{SAIRAALASIELUNHOITAJAN ASIANTUNTIJUUTEEN YHTEYDESSÄ OLEVAT TEKIJÄT}

Asiantuntijuuden osa-alueet olivat sielunhoitokeskustelun teemat potilaan kanssa, työskentelytavat ja potilaan tukemisen keinot, sielunhoitotyön tavoite, käsitys työn merkityksestä potilaille ja hoitajille, työtehtävät sekä ammatti-identiteetti.

Sairaalasielunhoitajan työvuosilla (alle viisi vuotta tai viisi vuotta ja yli) oli tilastollisesti merkitsevä yhteys sairaalasielunhoitajan työlleen asettamaan tavoitteeseen "potilaan lisääntynyt kyky tunnistaa ja käsitellä tunteita $(\mathrm{p}=0,046)$. Pidempään sairaalasielunhoitajana työskennelleille tavoite oli tärkeämpi. Alle viisi vuotta työskennelleistä kymmenen vastaajaa $(71.4 \%)$ valitsi vaihtoehdon "jokseenkin samaa mieltä ja yksi vastaaja $(7.1 \%)$ vaihtoehdon "täysin samaa mieltä”. Viisi vuotta tai enemmän työskennelleistä vastaajista $30(43.5 \%)$ valitsi vaihtoehdon "jokseenkin samaa mieltä” ja 29 (42\%) vaihtoehdon "täysin samaa mieltä". 
Työssäoloajalla ja eettisten kysymysten käsittelyllä potilaan kanssa, oli myös tilastollisesti merkitsevä yhteys $(\mathrm{p}=0,027)$. Alle viisi vuotta työskennelleistä vastaajista $30(35.7 \%)$ valitsi vaihtoehdon täysin tai jokseenkin eri mieltä. Viisi vuotta tai yli työskennelleistä vain kuusi $(7.2 \%)$ valitsi vaihtoehdon täysin tai jokseenkin eri mieltä ja $58(69.6 \%)$ valitsi vaihtoehdon jokseenkin tai täysin samaa mieltä. Muilla taustamuuttujilla (taulukkko1) ei ollut tilastollisesti merkitsevää yhteyttä sairaalasielunhoitajan asiantuntijuuteen.

\section{TUTKIMUKSEN LUOTETTAVUUS}

Tutkimuksen otos oli kattava, sillä kysely lähetettiin kaikille Suomen sairaalasielunhoitajille. Tutkimuksessa tarkasteltiin vastaajien kokemuksia heidän itsensä arvioimana. Kyselylomakkeen sisältövaliditeettia vahvistettiin esitestauksella, joka suoritettiin samalle kohdejoukolle, kuin varsinainen tutkimus (33). Sen avulla saatiin tietoa lomakkeen ymmärrettävyydestä, validiteetista ja reliabiliteetista (34). Esitestattujen palautteen perusteella kyselylomaketta täsmennettiin. Vastausprosentti oli hyvä $(63,4 \%)$. Aineisto analysoitiin tieteellisesti hyväksytyillä menetelmillä suhteessa aineiston kokoon ja mittarissa olevien muuttujien tasoon (35). Määrällisen aineiston analyysi tehtiin yhdessä tilastotieteilijän kanssa tutkimuksen luotettavuuden parantamiseksi. Taustamuuttujien, iän, koulutuksen ja työssäoloajan yhteyttä verrattiin työtä koskeviin kysymyksiin käyttäen tilastollisia testejä. Luotettavuutta ja selkeyttä parannettiin taulukoilla. Likert-asteikollisten kysymysten lisäksi vastaajilla oli mahdollisuus kuvata kokemustaan syvällisemmin täydentämällä vastauksiaan avointen kysymysten avulla. Yksityiskohtaiset vastaukset vähensivät tulkinnan mahdollisuutta, lisäten tutkimuksen validiteettia.

\section{POHDINTA}

Yli puolet sairaalasielunhoitajista oli suorittanut erityiskoulutuksen (60 op), mikä antaa hyvät valmiudet työhön. Muu lisäkoulutus ei merkittävästi kasvattanut ammatillista osaamista, vaikuttanut työskentelymenetelmiin, työn tavoitteisiin tai käsityksiin työhön kuuluvista asioista.

Keskustelussa potilaan kanssa sairaalasielunhoitajat käsittelivät eniten asioita, jotka liittyivät sairauden tai elämäntilanteen laukaisemiin kriiseihin sekä kuolemaan ja herättivät potilaassa pelkoa ja surua. Työskentelymenetelmät, kuten tunteiden vastaanottaminen ja myötäeläminen - osoittivat työskentelyn olevan terapeuttisesti orientoitunutta, vaikka sairaalasielunhoitajista vain kymmenellä prosentilla oli psykoterapeutin koulutus. Työskentelytapa osoittaa sielunhoitajan aitoa läsnäoloa itsessään ja vuorovaikutustilanteessa (23).

Potilaan kunnioittaminen näyttäytyi itsemääräämisoikeuden, yksityisyyden ja vakaumuksen tukemisena. Hengelliset elementit kuuluivat työhön potilaan tai läheisen toiveesta. Hengellisyys näyttäytyi asiantuntijuutena, ei niinkään uskonnollisena toimintana, vaikka sairaalasielunhoitajat pitivät omassa elämässä hengellisyyttä tärkeänä. Työmenetelmien osalta tulokset tukevat aikaisempia tutkimuksia (5). Työn painotuksen suhteen tulokset sekä tukevat kansainvälisiä tutkimuksia, että poikkeavat niistä. On todettu, että puolet sairaalasielunhoitajan vierailusta potilaan luona on uskonnollista toimintaa, kolmasosa henkistä ja viidesosa emotionaalista tukemista (27), toisissa tutkimuksissa puolestaan empaattinen kuunteleminen, tuki sairaudessa, ihmissuhdeongelmissa ja elämänvaikeuksissa ovat keskeisimmät elementit, uskonnollisen toiminnan osuus pienempi (20).

Sairaalasielunhoitajat kuvasivat ammattiidentiteettiä persoonaan liittyvillä ominaisuuksilla, kuten rauhallisuus ja empaattisuus. Ammattiroolissa suhtautuminen sielunhoidettavaan oli sallivaa ja asiakaslähtöistä. Tulos tukee aikaisempia tutkimuksia $(5,9,22)$. Vaikka sairaalasielunhoitajan työ edellyttää sosiaalista älykkyyttä (36), vain viidesosa vastaajista koki itsensä älykkääksi. Tunnistavatko sairaalasielunhoitajat oman asiantuntemuksensa?

Sairaalasielunhoitajat asettivat työskentelylleen tavoitteita, jotka ohjasivat työstämään tunteita potilaan kanssa ja auttoivat potilasta löytämään itsestään voimavaroja käsitellä asioita ja suuntautua uudelleen. Tavoitteista turvallisuuden tunteen lisääntyminen ja ihmisarvon vahvistuminen puolestaan tukivat potilaan tilanteessa toivoa. Tavoitteet vahvistivat potilaan kokemusta oman elämän hallinnasta kokonaisvaltaisemmin, eivätkä tähdänneet pelkästään potilaan selviytymiseen kohtaamishetkessä sairaalasielunhoitajan tuella. Tulokset tukevat aikaisempia tutkimuksia, mutta painottuvat eri tavalla $(5,15,17,18,20$, $26,28)$. 
Sairaalasielunhoitajien arvio potilaalle merkittävistä asioista heijastelee työntekijän roolissa tapahtunutta muutosta papista kriisituen ja terapeuttisorientoituneen tuen antajaksi. Merkityksellisiksi asioiksi hoitajille sairaalasielunhoitajat arvioivat hoitotyötä ja potilaan hoitoa tukevat toimet. Tulos eroaa aikaisemmista tutkimuksista, joiden mukaan sairaalasielunhoitaja edusti hengellistä ja uskonnollista maailmaa pyrkien vaikuttamaan potilaan uskoon $(23,28)$. Sairaalasielunhoitajien oma arvio työn merkityksellisyydestä kumpuaa keskeisistä työtehtävistä. Vaikuttaa siltä, että heitä hyödynnetään kriisityöntekijänä äkillisissä tilanteissa. Tutkimustulos tuki aikaisempia tutkimuksia $(18,20)$.

Sairaalasielunhoitajan työssään käsittelemien asioiden kirjo laajeni työssäolovuosien myötä. Laaja-alaisuuden lisääntyminen työvuosien myötä, merkitsee kasvua sielunhoitajana, kasvanutta kykyä tarkastella potilaan tilannetta monipuolisemmin ja tukea potilasta eettisissä pohdinnoissa (24). Potilaan tukeminen tunteiden tunnistamisessa ja käsittelyssä muodostui sitä merkittävämmäksi tavoitteeksi, mitä pidempäänsairaalasielunhoitaja oli työskennellyt. Tunteiden vastaanottaminen, työstäminen, kriisituki, työssä kehittyminen sekä laaja-alainen eettisten kysymysten käsittely edellyttävät työntekijältä itsereflektiota ja kykyä havainnoida omia ja toisen tunnetiloja ja suhtautumista niihin $(26,37)$.

Työskentely osoittaa sairaalasielunhoitajan kykyä hyödyntää kertynyttä kokemusta asiakastyöstä, vuorovaikutussuhteesta ja tietoa ihmisen arvoihin ja valintoihin vaikuttavista tekijöistä sekä taitoa yhdistää näitä työskentelyssään $(10,11,12)$.
Sairaalasielunhoitajan kokemuksella omasta asiantuntijuudesta ja työssäolovuosien välillä oli yhteys, mutta se ei ollut tilastollisesti merkittävä. Alle viisi vuotta työskennelleistä puolet piti itseään asiantuntevana, yli viisi vuotta työskennelleistä yhdeksän kymmenestä. Työkokemus vahvisti sairaalasielunhoitajan käsitystä omasta asiantuntijuudesta, mikä tukee aikaisempia tutkimustuloksia $(13,23)$.

Sairaalasielunhoitajan asiantuntijuus on taitoa kohdata ja tukea kriisissä olevaa, valmiutta käsitellä erilaisia tunteita, levollista vuorovaikutusta ja asiakaslähtöisyyttä. Osaamisensa kautta sairaalasielunhoitaja liittyy hoivayhteisöön potilaan kokonaisvaltaista hoitoa tukevana asiantuntijana.

\section{RAHOITTAJAT:}

Suomen kirkon pappisliitto, tutkimusapuraha.

\section{KIRJOITTAJIEN KONTRIBUUTIOT:}

Sipola on suunnitellut tutkimuksen, kerännyt ja analysoinut tutkimusaineiston sekä kirjoittanut artikkelin. Karvinen on ohjannut tutkimusprosessia ja kommentoinut artikkelikäsikirjoitusta. Huhtala on analysoinut artikkelin kvantitatiivista aineistoa ja mallintanut taustatietoja esittävän taulukon. Åstedt-Kurki, tutkimuksen seurantaryhmän jäsen, on kommentoinut artikkelikäsikirjoitusta. Aho on ohjannut tutkimusprosessia (tutkimuksen suunnittelu, toteutus, analyysi ja artikkelin kirjoittaminen) ja kommentoinut artikkelikäsikirjoitusta.

\section{Sipola, V., Karvinen, I., Huhtala, H., Astedt-Kurki, P.,Aho, AL. Hospital chaplains' description of their perceived}

expertise. Sosiaalilääketieteellinen aikakauslehti- Journal of Social Medicine 2020: 57: 32 I-33I.

The purpose of the study is to describe the expertise of hospital chaplaincy and related factors, as describe by hospital chaplains themselves $(n=83)$. The research material was collected from using an electronic questionnaire containing questions and related background information on the Likert-scale mentoring expertise. The data was analyzed by statistical methods.

In the conversation with the patient, hospital chaplains dealt mainly with illness, life crises and sadness. They mostly worked by listening, sym- pathizing, receiving the patient's feelings and discussing. Chaplains describe themselves as being reliable, calm and customer-oriented. For them, the most important values in the work were to respect the patient of the hospital chaplaincy and to support their self-determination and conviction. The key goals for chaplains in discussion with patient were maintaining hope and strengthening human dignity, and increasing the patient's sense of security. In their work, chaplains evaluate the important things for the patient the possibility 
discussing their fears and grief and getting support for dealing with them, for nurses the opportunity of having help when in crisis and the possibility of getting support and spiritual expert help for patients were important. The main tasks in their work were supportive conversation, support in the face of death and support for the mourning. The health care unit or additional training did not have a significant impact on the working methods, goals or perceptions of the work of the chap- lains. The supporting for the patient to identify and handle their emotions and the handling of ethical issues. Patient support for emotional identification and handling emotions and handling of ethical issues increased as work experience grew. Keywords: Pastoral care, chaplaincy service, hospital, spirituality

$$
\begin{array}{cc}
\text { Saapunut } & 12.07 .2019 \\
\text { Hyväksytty } & 09.03 .2020
\end{array}
$$

\section{LÄHTEET}

(1) Sairaalasielunhoidon periaatteet. Hyväksytty Kirkkohallituksen täysistunnossa. 17.8.2011. http://sakasti.evl.fi/sakasti.nsf/ sp3?open\&cid=Content3456FC

(2) Kirkon tutkimuskeskus. Osallistuva luterilaisuus. Suomen evankelis-luterilainen kirkko vuosina 2012-2015: Tutkimus kirkosta ja suomalaisista. Kirkon tutkimuskeskuksen julkaisuja 125. Grano Oy, Kuopio, 2016:24-46, 85-87, 205-206.

(3) Puchalski CM, Vitillo R, Hull SK, Reller N. Improving the Spiritual Dimension of Whole Person Care: Reaching National and International Consensus. Journal of Palliative Medicine 2014;17:642-656. https://doi.org/10.1089/jpm.2014.9427

(4) Piderman K, Sytsma T, Frost H, Novotny P, Rausch O, Solberg N, Patten C, Sloan J, Rummans T, Bronars C, Yang P, Clark M. Improving Spiritual Well-Being in Patients with Lung Cancers. Journal of Pastoral Care and Counseling 2015;69. https://doi.org/10.1177/1542305015602711

(5) Shields M, Kestenbaum A, Dunn B. Spiritual AIM and the work of the chaplain: A model for assessing spiritual needs and outcomes in relationship. Palliative and Supportative Care 2015;13:75-89. https://doi.org/10.1017/S1478951513001120

(6) Louheranta O, Lähteenvuo M, Kangasniemi M. Henkinen ja hengellinen tuki terveydenhuollossa - kenen vastuulla? Sosiaalilääketieteen aikakauskirja 2016;53:234-241.

(7) Tanyi RA, McKenzie M, Chapek C. How family practice physicians, nurse practitioners, and physician assistants incorporate spiritual care in practice. Journal of the American Association of Nurse Practitioners2009; 21:690-697. https://doi.org/10.1111/j.17457599.2009.00459.x

(8) Laki potilaan asemasta ja oikeuksista 17.8.1992 / 785. https://www.finlex.fi/fi/laki/ ajantasa/1992/19920785\#L2P6

(9) Räsänen J. Sielunhoito selviytymisen tukena sairaudessa ja kriiseissä. Väitöskirja. Kyselytutkimus terveydenhuollon potilaille ja työntekijöille. Kirkon Tutkimuskeskus. Tampere. 2005.
(10) Ranne K. Tutkivan oppimisen hanke. Topakka ja pedagoginen asiantuntijuus. Kirjassa: Heinilä H, Kalli P, Ranne K. (toim.) Tutkiva oppiminen ja pedagoginen asiantuntijuus. Saarijärvi: Saarijärven Offset Oy; 2009, 11.

(11) Palonen T, Gruber H. Satunnainen, rutiininomainen ja tietoinen osaaminen. Kirjassa: Collin K, Paloniemi S, Rasku-Puttonen H, Tynjälä P. (toim.) Luovuus, oppiminen ja asiantuntijuus. Helsinki: WSOYpro; 2010, 41-55.

(12) Tynjälä P. Konstruktivistinen oppimiskäsitys ja asiantuntijuuden edellytysten rakentaminen koulutuksessa. Kirjassa: Eteläpelto A, Tynjälä P. Oppiminen ja asiantuntijuus. Juva: WSOY Kirjapainoyksikkö; 1999b, 72-73.

(13) Eteläpelto A, Vähäsantanen K. Ammatillinen identiteetti persoonallisena ja sosiaalisena konstruktiona. Kirjassa: Eteläpelto A, Onnismaa J. (toim.) Ammatillisuus ja ammatillinen kasvu. Aikuiskasvatuksen vuosikirja; 2006:26-27.

(14) Kirkon tilastot. Sairaalasielunhoidon toimintatilastot 2018. https://www.kirkontilastot.fi/ viz?id=61

(15) Brown J, Gardner J. The Role of the Pastoral Practitioner in Health Outcomes and Wellbeing During Acute Illness: Exploring the Patient Experience of a Pastoral Visit. Journal of Pastoral Care \& Counseling 2017;71:230-236. https://doi.org/10.1177/1542305017742349

(16) Foskett J. Is There Evidence-based Confirmation of the Value of Pastoral and Spiritual Care? An Invitation to a Conversation. Somerset Partnership NHS Foundation Trust. HSCC (print) ISSN 1440-9917, 2013:83-90.

(17) Swinton J. Beyond Kindness: The Place of Compassion in a Forensic Mental Health Setting. Health and Social Care Chaplaincy 2013; 1.

(18) Detain J, Salter P. Meeting the Spiritual and Pastoral Needs of Patients and their Family at the End of Life. The Journal of Health Care Chaplaincy 2011;11:3-14.

(19) Nash P, Darby K, Nash S. The Spiritual care of sick children: reflections from a pilot participation project. International Journal of Children's Spirituality 2012;18:148-161. https://doi.org/10.1080/1364436X.2012.752345 
(20) Fitchett G. Recent Progress in ChaplaincyRelated Research. Journal of Pastoral Care and Counseling 2017;71:163-175. https://doi.org/10.1177/1542305017724811

(21) Swinton J. A question of identity: What does it mean for chaplains to become healthcare professionals? Scottish Journal of Healthcare Chaplaincy 2003;6. https://doi.org/10.1558/hscc.v6i2.2

(22) Nissilä K. Sairaalateologi saattohoitajana. Sielunhoidon aikakauskirja 2000:12, 54-56.

(23) Virtaniemi M-P. Sielunhoidon koulutus ja työnohjaus. Kirjassa: Aalto K, Esko M, Virtaniemi MP (toim.) Sielunhoidon käsikirja. Helsinki: Kirjapaja; 1998, 359.

(24) Hakala P. Sielunhoitajaksi kasvamassa. Seurakuntatutkimus sielunhoidon erikoistumiskoulutuksen osallistujista. Väitöskirja. Helsingin Yliopisto. Teologinen tiedekunta, käytännöllinen teologia. 2000.

(25) Carey L, Cobb M, Equell D. From pastoral contacts to pastoral interventions. Scottish Journal of Health Care Chaplaincy 2005;8: 14-20. https://doi.org/10.1558/hscc.v8.i2.14

(26) Harrison G. Towards a Collaborative Model of Pastoral Supervision. Journal of Health Care Chaplaincy 2011;11:23-31.

(27) Handzo GF, Flannelly KJ, Kudler T, Fogg L, Harding SR, Hasan YH, Ross AM, Taylor BE. What do chaplains really do? II. Interventions in the New York Chaplaincy Study. Journal of Health Care Chaplaincy 2008b: 14. https://doi.org/10.1080/08854720802053853

(28) Lindholm K. Handling Stereotypes of Religious Professionals: Strategies Hospice Chaplains Use When Interacting with Patients and Families. Journal of Pastoral Care and Counselling 2017;71:284-290. https://doi.org/10.1177/1542305017744493

(29) Sippo M. Kävitte katsomassa. Helsingin sairaalasielunhoito 1925-2000. Väitöskirja. Vammala. Suomalaisen teologinen kirjallisuusseura; 2004, 130-138, 145-150.

(30) Mamia T. SPSS - alkeisopas. Statistical Package for Social Sciences. Tampere. Tampereen Yliopisto. 2005.

(31) Saaranen-Kauppinen A, Puusniekka A. KvaliMOTV - Menetelmäopetuksen tietovaranto. Tampere: Yhteiskuntatieteellinen tietoarkisto; 2006. Luettu 12.4.2019. http://www.fsd.uta.fi/menetelmaopetus/>.
(32) TENK. Hyvä tieteellinen käytäntö ja sen loukkausepäilyjen käsitteleminen Suomessa. 2012. Luettu 24.1.2017. https://www.tenk.fi/fi/hyva-tieteellinen-kaytanto

(33) Heikkilä M. Tilastollinen tutkimus. Helsinki: Edita Oy; 2014,58.

(34) Burns N, Grove S-K. Understanding Nursing Research, building an Evidence-Based Practice. Fourth edition. St. Louis. Elsevier. USA.2011.

(35) Rattray J, Jones M. Essential elements of questionnaire design and development. Journal of Clinical Nursing 2007;16:234-243

(36) West JL. An Analysis of Emotional Intelligence Training and Pastoral Job Satisfaction. Journal of Pastoral Care and Counseling 2016; 70.

(37) Tiuraniemi J. 2002 Reflektiivisuus asiantuntijan työssä. Kirjassa: Niemi P, Keskinen E. (toim.) Taitavan toiminnan psykologia. Turun yliopiston psykologian laitos; Turku, 165-195.

\section{VIRPI SIPOLA \\ $T M, T t M$, johtava asiantuntija, Kirkkohallitus \\ Tampereen yliopisto \\ Yhteiskuntatieteiden tiedekunta, Terveystieteet, Hoitotiede.}

\section{IKALI KARVINEN \\ Tt $T$, maajohtaja \\ Kirkon ulkomaanapu \\ Tutkija \\ Itä-Suomen yliopisto}

\section{Heini Huhtala}

FM, yliopisto-opettaja

Tampereen yliopisto

Yhteiskuntatieteiden tiedekunta, Terveystieteet

\section{PäIVI ÅstedT-KuRKI}

THT, professori

Tampereen yliopisto

Yhteiskuntatieteiden tiedekunta, Hoitotiede

Anna LiIsa Aho

TtT, dosentti, yliopistonlehtori

Tampereen yliopisto

Yhteiskuntatieteiden tiedekunta, Hoitotiede 